\title{
Apolipoprotein (Apo) E Inhibits the Capacity of Monosodium Urate Crystals to Stimulate Neutrophils \\ Characterization of Intraarticular Apo E and Demonstration of Apo E Binding to Urate Crystals in Vivo
}

Robert A. Terkeltaub, Cheryl A. Dyer, Jody Martin, and Linda K. Curtiss

San Diego Veterans Administration Medical Center, Department of Medicine, University of California San Diego School of Medicine; Division of Immunology, Scripps Clinic and Research Foundation, La Jolla, California 92037

\begin{abstract}
Factors that modulate the ability of monosodium urate crystals to stimulate leukocytes could regulate gouty inflammation. $\mathrm{Li}$ poproteins that bear apo B-100 and apo $E$ bind to urate crystals and suppress crystal-neutrophil interaction. In this study, we observed that urate crystals, coated with apo $E$ of monocyte origin, had a diminished ability to stimulate neutrophils. Apo E was also detected on the surface of urate crystals recovered from gout patients. Thus, we analyzed apo $E$ in noninflammatory synovial fluid, and found it to be associated with particles of heterogeneous size and of predominantly alpha and pre-beta electrophoretic mobility. Local articular synthesis of at least a portion of synovial fluid apo $E$ was suggested because $(a)$ the synovial fluid/plasma concentration ratio of apo $\mathbf{E}$ was significantly higher than that for both apo $B$ and apo A-I, which are not widely synthesized by extrahepatic tissues, (b) cultured rheumatoid synovial cells in first passage secreted apo $\mathrm{E}$, (c) a portion of synovial fluid apo $\mathbf{E}$ was heavily sialylated.

We conclude that synovial fluids contain apo $E$ that appears partly of local origin. Apo E binds to urate crystals and could modulate gouty inflammation. (J. Clin. Invest. 1991. 87:2026.) Key words: gout • synovial fluid • synovium • apolipoprotein B • apolipoprotein A-1
\end{abstract}

\section{Introduction}

Monosodium urate crystals encounter leukocytes in the synovial joints and periarticular bursae of individuals with gout (1), resulting in the release of inflammatory mediators that can trigger acute inflammation (2-5). However, the inflammatory response associated with free urate crystals in joints and bursae is highly variable $(4,5)$. Thus, much effort has been directed towards the characterization of factors which suppress urate crystal-induced leukocyte stimulation.

In this regard, it has been observed that urate crystals in clinically quiescent tophaceous synovial deposits are physically associated with variable amounts of surface proteins (6) and of lipids including esterified cholesterol $(1,7)$. Furthermore, a number of individual plasma proteins and lipoproteins bind to the surface of urate crystals and can alter their inflammatory

Address correspondence to Dr. R. Terkeltaub, VA Medical Center (V$111 \mathrm{~K}), 3350$ La Jolla Village Drive, San Diego, CA 92161.

Received for publication 8 June 1990 and in revised form 17 August 1990.

J. Clin. Invest.

(c) The American Society for Clinical Investigation, Inc. 0021-9738/91/01/0020/07 \$2.00

Volume 87, January 1991, 20-26 potential in vitro (8-10). Significantly, when urate crystals are coated with plasma their ability to stimulate neutrophils in vitro is markedly diminished (10-12), an effect caused by the binding to crystals of lipoproteins bearing apolipoprotein (apo) ${ }^{1}$ B-100 (LDL) and apo B-100 and apo E (VLDL, IDL) (10-12). Apo B-100 mediates the binding of LDL to urate crystals and is itself able to suppress urate crystal-induced neutrophil stimulation (13). In this study, we demonstrate that apo E is also a potent inhibitor of the ability of urate crystals to stimulate neutrophils in vitro and that apo $\mathrm{E}$ is bound to urate crystals recovered from patients with gout.

These observations prompted us to quantify and characterize the apo E of synovial fluids. Apo E, in distinction to other apolipoproteins, is synthesized by both the liver and by numerous extrahepatic tissues, including cells of the monocyte/macrophage lineage (14-16). The apo E newly secreted by extrahepatic cells, including macrophages, is heavily sialylated (16, 17), which helps to distinguish it from the apo $E$ found in circulating plasma lipoproteins $(16,17)$, which is totally or nearly totally desialylated via unknown mechanisms (17).

Apo $\mathrm{E}$ functions in lipid redistribution between tissues by serving as a ligand for the low density lipoprotein (LDL) receptor (15) and for a second, postulated receptor for chylomicron remnants (18). Apo E also can function in tissue repair by modulating lipid redistribution locally $(15,19)$. Last, apo $\mathrm{E}$ also possesses a variety of functions that are not related to lipid transport (15), including suppression, by apo E-bearing lipoproteins and by apo $\mathrm{E}$ polypeptides, of lymphocyte activation (20-23).

In this study, we demonstrate that apo $\mathrm{E}$ is present in human synovial fluids at substantial concentrations and we provide evidence for the presence there of apo $E$ of local origin. These observations suggest that apo E may also have important functions within synovial joints.

\section{Methods}

Collection and treatment of synovial fluids. Synovial fluids, sera, and plasma were collected simultaneously from patients undergoing diagnostic procedures at the San Diego Veterans Administration Medical Center. Additional synovial fluids were a generous gift of Dr. G. Firestein (UCSD Medical Center, San Diego) and Dr. P. Fowler (University of Western Ontario, London, Ontario). Only nonhemorrhagic synovial fluids were studied. Patients with osteoarthritis were verified to have noninflammatory effusions and the absence of detectable intraleukocytic monosodium urate or calcium pyrophosphate crystals by compensated polarized light microscopy at $400 \times$ magnification (24). Patients with acute gout were confirmed to have intraleukocytic urate

1. Abbreviation used in this paper: apo, apolipoprotein. 
crystals (24). Patients with Reiter's disease and rheumatoid arthritis had active disease and met accepted diagnostic criteria.

All synovial fluids, sera, and plasmas were treated with EDTA (5 $\mathrm{mM})$, phenylmethylsulfonylfluoride (PMSF) $(100 \mu \mathrm{M})$ and aprotinin $(0.01 \%)$ and centrifuged $\left(6,900 \mathrm{~g}\right.$ for $30 \mathrm{~min}$ at $\left.4^{\circ} \mathrm{C}\right)$ to remove cells and particulates. Treatment of synovial fluids with $100 \mu \mathrm{g} / \mathrm{ml}$ of testicular hyaluronidase (Sigma Chemical Co., St. Louis, MO) was carried out for $3 \mathrm{~h}$ at $37^{\circ} \mathrm{C}$ to reduce viscosity and enable accurate pipetting (25). It was verified that identical treatment with hyaluronidase did not alter the measurement of apolipoproteins.

Isolation of plasma lipoproteins. The major lipoprotein density fractions were isolated from plasma by standard ultracentrifugation techniques in the presence of protease inhibitors and antioxidants as described (26). LDL and HDL were of $d=1.019-1.063 \mathrm{~g} / \mathrm{ml}$ and $d$ $=1.063-1.25 \mathrm{~g} / \mathrm{ml}$, respectively.

Quantitation of cholesterol, triglycerides, and apolipoproteins $E, B$, and $A-I$. Total cholesterol was measured enzymatically using the Boehringer Mannheim Diagnostics (Indianapolis, IN) high performance cholesterol reagent, and total triglycerides measured using the enzymatic triglyceride reagent from Abbott Laboratories (Irving, TX). Apo $E$ was quantitated by radioimmunoassay (27), and apo B and apo A-I by ELISA as previously described $(28,29)$. Protein concentrations of apo E, LDL, and HDL were measured by a modification of the Lowry method (30).

Synovial fluid/plasma concentration ratios of apolipoproteins, cholesterol and triglycerides were compared using the paired, two-tailed $t$ test as implemented with the Statview II program (Abacus Concepts, Inc., Berkeley, CA) on a Macintosh SE computer.

Electrophoresis and identification of apolipoproteins by Western blotting. Nondenaturing polyacrylamide (31), and agarose gel electrophoreses (13) were performed as previously described. Molecular weight standards for sizing gels were thyroglobulin $(669 \mathrm{kD})$, ferritin (440 kD), catalase (232 kD), lactate dehydrogenase (140 kD), albumin (67 kD). For 13\% SDS-PAGE we employed, as standards: phosphorylase $b(94 \mathrm{kD})$, albumin $(67 \mathrm{kD})$, ovalbumin $(43 \mathrm{kD})$, carbonic anhydrase $(30 \mathrm{kD})$, trypsin inhibitor $(20.1 \mathrm{kD})$, alpha-lactalbumin $(14.4$ $\mathrm{kD})$, and we employed apo $\mathrm{E}$ as an internal standard.

Gels were transferred to nitrocellulose paper that was probed for apolipoproteins as previously described, using antibodies IE (apo Especific), B47 (apo B-specific), and a pool of apo A-I-specific antibodies (A-I-4, A-I-7, and A-I-10) (26). Neuraminidase treatment (16) of synovial fluid before electrophoresis was performed, by incubating 0.1 $\mathrm{ml}$ of whole synovial fluid with $0.1 \mathrm{ml}$ of $0.1 \mathrm{M}$ sodium acetate $(\mathrm{pH} 4.0)$ containing 1.5 units of $C$. perfingens neuraminidase (Sigma Chemical Co.) at $37^{\circ} \mathrm{C}$ for $24 \mathrm{~h}$. Samples were extracted with $3 \mathrm{ml}$ of ethanol:ether $(3: 1)$ at $-20^{\circ} \mathrm{C}$ for $30 \mathrm{~min}$, and the pellet was washed once with diethyl ether (16).

To study urate crystals isolated from gouty patients, we isolated the crystals by repeated sedimentation of the fluids $(1,000 \mathrm{~g}$ for $10 \mathrm{~min})$, and crystals were washed in distilled water to lyse cells (32). Proteins were eluted from the crystal surface by boiling in SDS under reducing conditions (9), and were electrophoresed in $13 \%$ polyacrylamide gels.

Synovial cell isolation and culture. Synovial cells isolated from surgical specimens freshly removed from a patient undergoing joint replacement for rheumatoid arthritis, were a generous gift of Dr. Martin Lotz (Scripps Clinic). Collagenase digestion and culture were performed essentially as described (33). Cells were maintained in DMEM supplemented with L-glutamine, penicillin, streptomycin, and $10 \%$ FCS. At confluency the cells were trypsinized, divided 1:3, washed and recultured at 100,000 cells $/ 25 \mathrm{~cm}^{3}$ flask in $4.5 \mathrm{ml}$ of a serum-free medium that comprised DMEM supplemented with $20 \mathrm{mM}$ Hepes, $1 \mathrm{mM}$ Na pyruvate, $1 \%$ BSA, and $1 \%$ Nutridoma-HU (Boeringer Mannheim Diagnostics). After $7 \mathrm{~d}$ the supernatants were recovered by centrifugation and the medium assayed for apo $\mathrm{E}$ by radioimmunoassay.

$T H P-1$ cell culture and isolation of secreted apo $E$. THP-1 cells were obtained from the American Type Culture Collection (Rockville, MD) and maintained in suspension in T-150 culture flasks (Costar, Cambridge, MA) at a cell density of 0.2 to $1.0 \times 10^{6} / \mathrm{ml}$ in $100 \mathrm{ml}$ of RPMI-
1640 containing 7\% FCS (Rehatuin F.S., Armour Pharmaceutical, Kankakee, IL), $10 \mathrm{mM}$ Hepes, $2 \mathrm{mM}$ glutamine, Pen-Strep (penicillin, $200 \mathrm{U} / \mathrm{ml}$; streptomycin, $2 \mathrm{mg} / \mathrm{ml}$; Sigma Chemical Co.), $1 \mathrm{mM}$ sodium pyruvate and $5 \times 10^{-5} \mathrm{M}$ beta-mercaptoethanol.

To stimulate apo $E$ production the cells were washed three times in the above medium with $1 \%$ Nutridoma-HU instead of FCS. The cells were seeded in T-150 flasks $\left(100 \mathrm{ml}\right.$ at $\left.1 \times 10^{6} / \mathrm{ml}\right)$ and stimulated with phorbol myristate acetate $(100 \mathrm{nM})$. After $7 \mathrm{~d}$ of culture the medium was collected and the adherent cells refed with fresh medium. In this manner, medium containing apo $\mathrm{E}$ was collected four times from the same culture flask. The pooled conditioned media were stored at $-20^{\circ} \mathrm{C}$.

To purify the apo E, the medium was filtered through a $0.45-\mu \mathrm{m}$ filter and applied to an immunoaffinity column. The column was prepared by coupling $11 \mathrm{mg}$ of purified monoclonal antibody (1E) to 14 $\mathrm{ml}$ of Affigel HZ (Bio-Rad Laboratories, Richmond, CA) according to a protocol from the manufacturer that exhibited $>99 \%$ coupling efficiency. Conditioned medium $(100 \mathrm{ml})$ was applied to the column for each isolation. Bound apo $\mathrm{E}$ was eluted with $5 \mathrm{M}$ guanidine $\mathrm{HCl}$ and exhaustively dialyzed against PBS.

Neutrophil isolation and assay of urate crystal-induced alpha-mannosidase release. Human neutrophils were isolated from normal volunteers via Ficoll-Hypaque centrifugation as previously described (10). These preparations consistently contained $>98 \%$ neutrophils. We incubated neutrophils $\left(4 \times 10^{6} / \mathrm{ml}\right.$ in a buffer containing $147 \mathrm{mM} \mathrm{NaCl}$, $5 \mathrm{mM} \mathrm{KCl}, 1.9 \mathrm{mM} \mathrm{KH}_{2} \mathrm{PO}_{4}, 1.1 \mathrm{mM} \mathrm{Na}_{2} \mathrm{HPO}_{4}, 5.5 \mathrm{mM}$ glucose, 3 $\mathrm{mM} \mathrm{MgSO}_{4}, 1 \mathrm{mM} \mathrm{MgCl}, 1.5 \mathrm{mM} \mathrm{CaCl}, 10 \mathrm{mM}$ Hepes, and 2.5 $\mathrm{mg} / \mathrm{ml} \mathrm{BSA}$, pH 7.4), with urate crystals $(1 \mathrm{mg} / \mathrm{ml})$ for $30 \mathrm{~min}$ at $37^{\circ} \mathrm{C}$ in a volume of $0.5 \mathrm{ml}$. The reactions were terminated by centrifugation and alpha-mannosidase release was measured at $405 \mathrm{~nm}$ (10).

Synthetic urate crystals were prepared and characterized as previously described (10), and were coated with apo $\mathrm{E}$ (or controls) at up to $10 \mu \mathrm{g} /$ protein per $\mathrm{ml}$ in a total volume of $0.25 \mathrm{ml} 10 \mathrm{mM} \mathrm{PBS}, \mathrm{pH}$ 7.4. The buffer was saturated with urate before use to prevent crystal dissolution $(9,10)$ and it contained $2 \mathrm{mg} / \mathrm{ml} \mathrm{BSA}$ as a physiologic background protein $(9,10)$. After incubation with proteins the urate crystals were washed three times before incubation with neutrophils.

\section{Results}

Apo E binds to urate crystals and inhibits urate crystal-induced neutrophil stimulation. Apo E-containing plasma lipoproteins have been previously observed to bind to urate crystals exposed to human serum and plasma in vitro (10). In this study, we observed that apo $\mathrm{E}$ bound to the surface of washed synthetic urate crystals that had been incubated with gouty joint fluid (Fig. 1, lane 2). Thus, we studied urate crystals aspirated from patients with gout and detected bound apo $\mathrm{E}$ on washed urate crystals in four of four patients studied, including crystals from the knee joint and olecranon bursa of two representative pa-

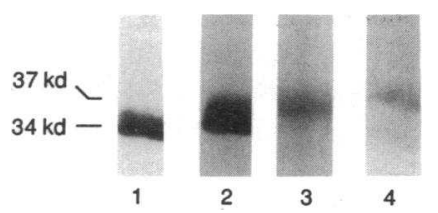

Figure 1. Apo $\mathrm{E}$ is bound to monosodium urate crystals in vivo and in vitro. Samples were separated by SDS-PAGE in a $13 \%$ gel and probed for apo $\mathrm{E}$ after transfer to nitrocellulose by Western blotting with an apo E-specific antibody as described in Methods: apo E of plasma VLDL (lane 1) served as an internal standard; protein eluted from $10 \mathrm{mg}$ washed synthetic urate crystals that were previously coated with $0.1 \mathrm{ml}$ gouty synovial fluid (lane 2); protein eluted from washed urate crystals (20 $\mathrm{mg}$ ) aspirated from an asymptomatic gouty knee joint (lane 3); and an asymptomatic gouty olecranon bursa (lane 4 ). 


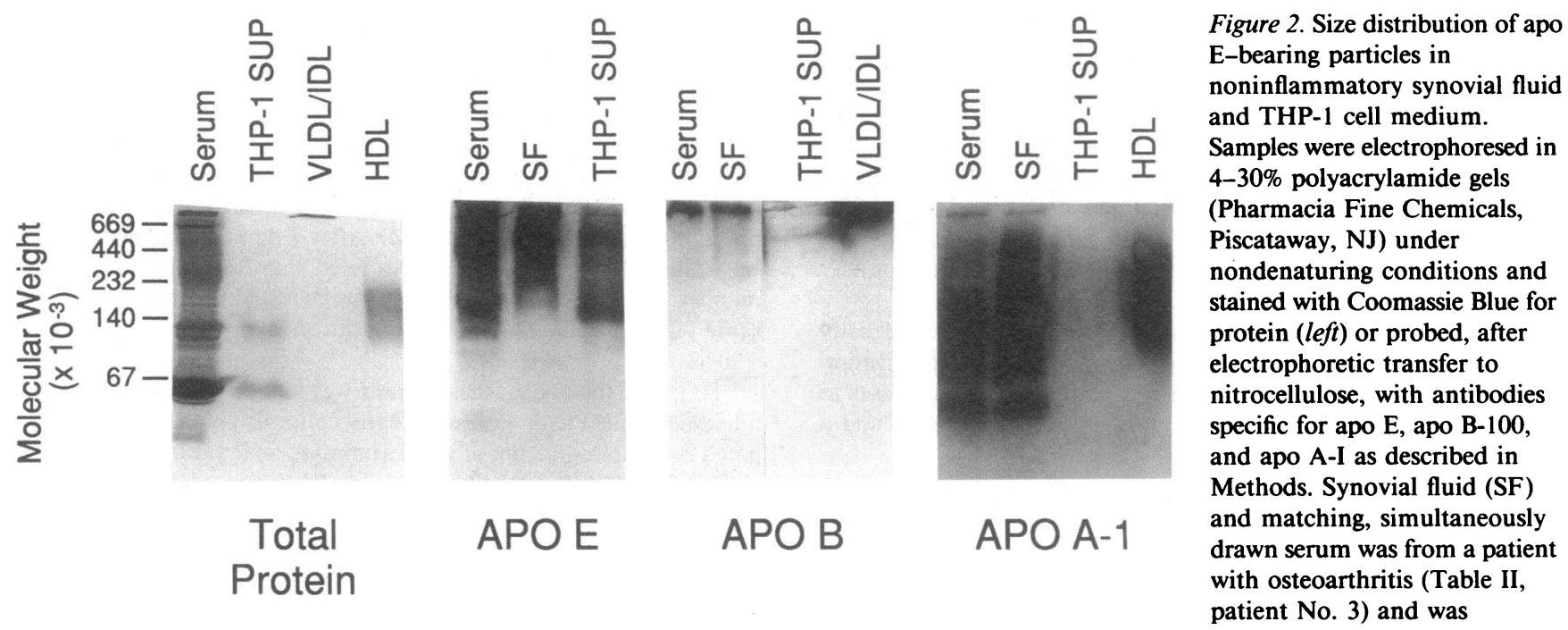

representative of three separate patients studied. HDL, VLDL/IDL, and THP-1 cell supernatants were prepared as described in Methods.

tients (Fig. 1, lanes 3 and 4). Therefore, apo E binds to urate crystals in vitro and in vivo.

Lipoproteins containing only apo B-100 (LDL), and both apo B-100 and apo E (VLDL and IDL), suppress neutrophil activation by urate crystals (10). To determine if apo E could modulate this function we studied particles that contained only apo $\mathrm{E}$. To do so, apo $\mathrm{E}$ was isolated via immunoaffinity chromatography of the conditioned media of human myelomonocytic leukemia cells (THP-1 cells) grown in serum-free medium. These particles were verified to be free of both apo $B$ and apo A-I (Fig. 2) but to contain phospholipid (27) and apo E (Fig. 2).

Coating of urate crystals with THP-1 cell-derived apo E (at up to $10 \mu \mathrm{g}$ protein $/ \mathrm{ml}$ ) resulted in progressive inhibition of urate crystal-induced release of the neutrophil azurophil granule constituent, alpha-mannosidase (Fig. 3). THP-1 cell apo E, added directly to cells at these concentrations, did not inhibit alpha-mannosidase release from cytochalasin B-treated neutrophils exposed to $1 \mu \mathrm{M} \mathrm{N}$-formyl-met-leu-phe (not shown). Thus, the inhibition of the ability of apo E-coated urate crystals to stimulate neutrophils was not due to direct effects of apo $E$ on the functional integrity of neutrophils.

The inhibitory capacity of apo $\mathrm{E}$ for urate crystal-induced neutrophil stimulation was comparable with that of human plasma LDL, which was utilized as a positive control (10) (Fig. 3 ). Furthermore, we confirmed (10) that the potent inhibitory activities of apo E, and of LDL, were not shared by apo E-poor HDL (Fig. 3), which also binds to urate crystals (10). In addition, the fraction of THP-1 cell conditioned media that was not retained by the apo $\mathrm{E}$ immunoadsorbant (and which contained $<0.1 \mu \mathrm{g} / \mathrm{ml}$ apo E) was essentially noninhibitory for urate crystal-induced neutrophil activation at identical total protein concentrations (Fig. 3).

Quantification of apo $E$ in synovial fluid. Because low concentrations of apo E had marked effects on urate crystal-induced neutrophil stimulation, we looked for evidence that apo $\mathrm{E}$ was present in synovial fluids. We first assessed the concentration of apo $\mathrm{E}$ in synovial fluids relative to the plasma concentration of apo $\mathrm{E}$ in normal volunteers and we compared this ratio to that for apo $B$ and apo A-I.

The ratio of the concentration of synovial fluid apo $E$ to a mean normal plasma concentration (obtained from a panel of 20 unmatched normal donors) was significantly greater than the same ratio for apo B and for apo A-I in both 21 noninflam-

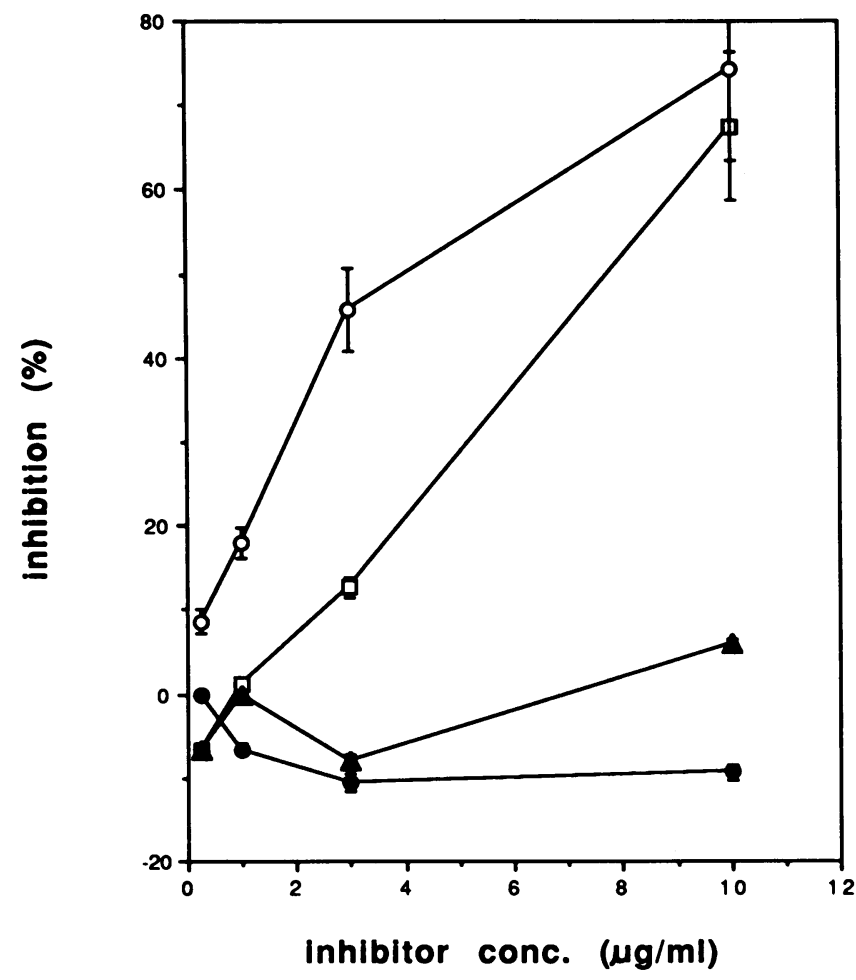

Figure 3. Apo E inhibits neutrophil responsiveness to monosodium urate crystals. Synthetic urate crystals were incubated with apo E that was separated from THP-1 cell conditioned medium by immunoaffinity chromatography (o), the unbound fraction from the same immunoaffinity column (ه), normal plasma LDL () or HDL

$(\bullet)$ at the indicated protein concentrations in urate-saturated buffer containing albumin. Crystals were washed three times and added in triplicate (at $1 \mathrm{mg} / \mathrm{ml}$ ) to human neutrophils in $0.5 \mathrm{ml}$ for $30 \mathrm{~min}$ at $37^{\circ} \mathrm{C}$, and alpha-mannosidase release was measured as described in Methods. Crystals coated in buffer alone induced release of $24.5 \%$ of total neutrophil alpha-mannosidase. Representative of seven separate experiments. 
Table I. Synovial Fluid (SF)/Plasma Ratio of Apo B-100, Apo A-I, and Apo E

\begin{tabular}{lcccc}
\hline \multicolumn{1}{c}{ Diagnosis } & $n$ & $\begin{array}{c}\text { Apo B: } \\
\text { SF/plasma } \\
\text { ratio }\end{array}$ & $\begin{array}{c}\text { Apo A-I: } \\
\text { AF/plasma } \\
\text { ratio }\end{array}$ & $\begin{array}{c}\text { Apo E: } \\
\text { SF/plasma } \\
\text { ratio }\end{array}$ \\
\hline $\begin{array}{l}\text { Noninflammatory } \\
\quad \text { OA }\end{array}$ & 21 & $0.18 \pm 0.04$ & $0.27 \pm 0.04$ & $0.58 \pm 0.04^{*}$ \\
Inflammatory & & & & \\
$\quad$ RA & 23 & $0.44 \pm 0.03$ & $0.56 \pm 0.07$ & $0.81 \pm 0.06^{*}$ \\
$\begin{array}{l}\text { Acute gout } \\
\text { Reiter's }\end{array}$ & 13 & $0.42 \pm 0.07$ & $0.26 \pm 0.04$ & $0.72 \pm 0.07^{*}$ \\
& 11 & $0.38 \pm 0.08$ & $0.57 \pm 0.07$ & $0.84 \pm 0.06^{*}$ \\
\hline
\end{tabular}

The concentrations of apolipoproteins in pathologic synovial fluids, and in the plasmas of a panel of 20 unmatched, normal donors were measured by SPRIA. (Plasma values for the panel of normals for these assays were: apo B, $979 \pm 48 \mu \mathrm{g} / \mathrm{ml}$; apo A-I, $1.87 \pm 0.25 \mathrm{mg} / \mathrm{ml}$; apo $\mathrm{E}, 86 \pm 4 \mu \mathrm{g} / \mathrm{ml}$ ). The data represents the mean ratios for apolipoproteins of [SF concentration]/[mean plasma concentration in panel of unmatched normals donors]. OA, osteoarthritis; RA, rheumatoid arthritis. ${ }^{*} P<0.001$ vs. apo B and apo A-I.

matory and 47 inflammatory synovial fluids (Table I). To confirm these results we studied a smaller, separate panel of subjects from whom paired joint fluid and plasma samples were obtained. Because the plasma concentrations of cholesterol, triglycerides, and certain lipoproteins can vary during the day (34), we drew plasma samples from each individual at the time of arthrocentesis. The ratio of synovial fluid/plasma concentration for apo $\mathrm{E}$ in the paired samples was also significantly greater than that for apo, B apo A-I, total cholesterol, and triglycerides (Table II). Importantly, the concentrations of apo $\mathrm{E}$ $(5.1-19.5 \mu \mathrm{g} / \mathrm{ml}$ measured by immunoassay, Table II) were similar to those at which apo $\mathrm{E}$ (as measured in the same assay) could inhibit the capacity of urate crystals to activate neutrophils (Fig. 3).
These results suggested that apo $E$ was enriched relative to apo B and apo A-I in synovial fluids. Because apo B and apo A-I would be expected to enter synovial fluids exclusively by filtration from plasma $(35,36)$ these observations pointed to the possibility that a fraction of synovial fluid apo E was locally produced.

Further evidence for local articular synthesis of apo E. Apo E, newly secreted as a constitutive product of a number of extrahepatic tissues, including cells of the monocyte/macrophage lineage (16), is heavily sialylated and, in SDS-PAGE, migrates distinctly (17) from the apo $\mathrm{E}$ of circulating plasma lipoproteins, which is largely desialylated $(16,17)$. We observed that a fraction of apo $\mathrm{E}$ in osteoarthritic synovial fluids migrated with an elevated apparent molecular weight of 36-37 $\mathrm{kD}$ upon SDS-PAGE, comparable with that of apo E of THP-1 cell origin (Fig. 4). Treatment of whole synovial fluids with neuraminidase (16) resulted in a reduction of molecular weight of all synovial fluid apo E to $34 \mathrm{kD}$ on SDS-PAGE (Fig. 4). Thus, synovial fluid apo $\mathrm{E}$ included a $36-37 \mathrm{kD}$ fraction that was comparable to other apo Es of known extrahepatic origin, including apo $\mathrm{E}$ of monocyte/macrophage origin.

Monocyte/macrophage lineage cells (along with fibroblastlike cells) constitute the cells (synoviocytes) lining the inner surface of synovium (33). In addition, macrophages are normal constituents of synovial fluid (37) and are known to be present in cultures of synovial lining cells in early passages (33). Thus, cells isolated from the synovium of a patient with rheumatoid arthritis were studied in first passage in tissue culture. After $7 \mathrm{~d}$ the release of a small amount of apo $E$ into the serum-free media was detectable by immunoassay $(158.4 \mathrm{ng} / 100,000$ cells). This further supported evidence for local intraarticular synthesis of apo $\mathrm{E}$.

Qualitative analysis of apo E-bearing particles in synovial fluids. We observed that the molecular weight of synovial fluid apo E on SDS-PAGE was heterogeneous (Fig. 4), suggesting heterogeneity of the cellular origin of the apo $\mathrm{E}$ in synovial fluid. To evaluate if the particles bearing apo $E$ in synovial

Table II. Concentrations of Apo E, Cholesterol, Triglycerides and Ohter Apolipoproteins in Synovial Fluids Relative to Matched Plasmas

\begin{tabular}{lccccc}
\hline & \multicolumn{5}{c}{ Synovial fluid concentration/plasma concentration (ratio) } \\
\cline { 2 - 6 } \multicolumn{1}{c}{$\begin{array}{c}\text { Patient's } \\
\text { diagnosis }\end{array}$} & $\begin{array}{c}\text { Total } \\
\text { cholesterol }\end{array}$ & Triglycerides & Apo B & Apo A-I & \\
\hline & $m g / d l$ & $m g / d l$ & $\mu g / m l$ & $\mu g / m l$ & \\
1. OA & $41 / 127(0.32)$ & $19 / 108(0.18)$ & $123 / 597(0.21)$ & $293 / 1,050(0.28)$ & $5.1 / 11.1(0.46)$ \\
2. OA & $169 / 232(0.73)$ & $51 / 154(0.33)$ & $458 / 829(0.55)$ & $521 / 1,024(0.51)$ & $7 / 12.4(0.56)$ \\
3. OA & $42 / 252(0.17)$ & $3 / 201(0.01)$ & $155 / 1,190(0.13)$ & $247 / 1,550(0.16)$ & $8.8 / 33.6(0.26)$ \\
4. OA & $64 / 218(0.29)$ & $39 / 134(0.29)$ & $<10 / 860(0)$ & $53 / 1,518(0.03)$ & $6.3 / 16.2(0.39)$ \\
5. Acute gout & $118 / 183(0.64)$ & $80 / 147(0.54)$ & $509 / 937(0.54)$ & $973 / 1,545(0.63)$ & $19.5 / 20.5(0.95)$ \\
6. Reiter's & $70 / 154(0.45)$ & $24 / 79(0.30)$ & $164 / 762(0.22)$ & $561 / 1,524(0.37)$ & $6.4 / 9.4(0.68)$ \\
7. Reiter's & $119 / 159(0.75)$ & $50 / 79(0.63)$ & $370 / 1,096(0.34)$ & $576 / 1,514(0.38)$ & $8.1 / 10.1(0.80)$ \\
8. RA & $76 / 137(0.55)$ & $16 / 71(0.23)$ & $180 / 654(0.28)$ & $339 / 839(0.40)$ & $5.3 / 8.7(0.61)$ \\
9. RA & $130 / 210(0.62)$ & $68 / 161(0.42)$ & $386 / 947(0.41)$ & $1055 / 1,714(0.62)$ & $11.3 / 16.2(0.70)$ \\
10. RA & $87 / 146(0.60)$ & $38 / 89(0.43)$ & $293 / 721(0.41)$ & $751 / 978(0.77)$ & $7.8 / 11.5(0.68)$ \\
11. RA & $119 / 187(0.64)$ & $31 / 73(0.42)$ & $312 / 755(0.41)$ & $832 / 1,950(0.43)$ & $15 / 29(0.52)$ \\
12. RA & $78 / 164(0.48)$ & $24 / 94(0.26)$ & $282 / 872(0.32)$ & $457 / 1,520(0.30)$ & $13.6 / 18(0.76)$ \\
Mean ratio & $(0.52 \pm 0.17)$ & $(0.34 \pm 0.16)$ & $(0.32 \pm 0.15)$ & $(0.40 \pm 0.20)$ & $(0.61 \pm 0.18)^{*}$ \\
& & & & & \\
\hline
\end{tabular}

Plasma samples were drawn from each individual at the time of arthrocentesis. OA, osteoarthritis; RA, rheumatoid arthritis. ${ }^{*} P<0.001$ vs. triglycerides and apo B, $P<0.01$ vs. apo A-I, $P<0.05$ vs. cholesterol. 


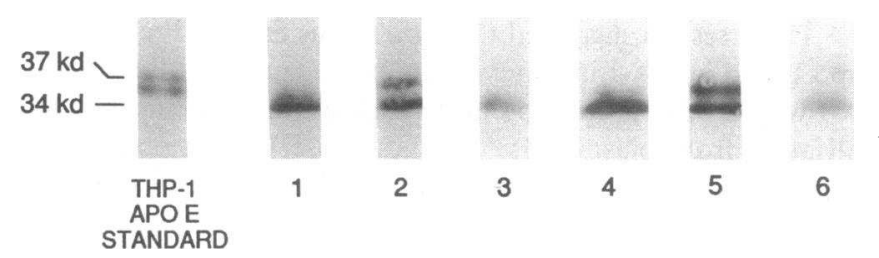

Figure 4. Elevated molecular weight of a fraction of synovial fluid apo E. Samples $(0.015 \mathrm{ml})$ from two different osteoarthritis patients (Table II, patients No. 3 and 4), representative of four patients studied, were electrophoresed in a $13 \%$ SDS-PAGE gel, electrophoretically transferred to nitrocellulose and probed for apo $\mathrm{E}$. Apo E of THP-1 cell origin served as an internal standard (left); serum or plasma from the patients (lanes 1 and 4); synovial fluids (lanes 2 and 5); synovial fluids after neuraminidase digestion (lanes 3 and 6).

fluids also were heterogeneous, we utilized nondenaturing polyacrylamide gradient gel electrophoresis (31) and agarose gel electrophoresis (13) followed by Western blotting (Figs. 2 and 5 ). These methods were employed in preference to density gradient ultracentrifugation because artifactual dissociation of apo $\mathrm{E}$ from lipoproteins can be induced by ultracentrifugation $(38,39)$. To minimize the contribution of filtered plasma lipoproteins to the content of apo E-bearing particles we studied noninflammatory synovial fluids and found apo $E$ there to be associated with particles of a broad range of sizes (Fig. 2). These included particles, equivalent in size to proteins $>669 \mathrm{kD}$, that comigrated with apo B-lipoproteins on nondenaturing polyacrylamide sizing gels (Fig. 2) and particles that were equivalent in size to proteins of $\sim 500$ and $230 \mathrm{kD}$, and that comigrated with HDL particles (Fig. 2). In contrast, apo B-bearing particles in synovial fluid were universally $>669 \mathrm{kD}$, and were entirely excluded from the sizing gels (Fig. 2).

The absence of free apo E (34 kD) on sizing gels (Fig. 2) suggested that apo $\mathrm{E}$ in synovial fluid could be associated with lipoproteins. This observation was supported by the demonstration that synovial fluid apo E floated at a density of $<1.25 \mathrm{~g} / \mathrm{ml}$ when synovial fluid was subjected to density gradient ultracentrifugation (data not shown). In addition, synovial fluid apo $\mathrm{E}$ migrated with lipoproteins into nondenaturing agarose gels (13) (Fig. 5), where the apo E-bearing lipoproteins were seen to be predominantly alpha (comigrating with HDL) and pre-beta (intermediate in charge between HDL and LDL) (Fig. 5). The

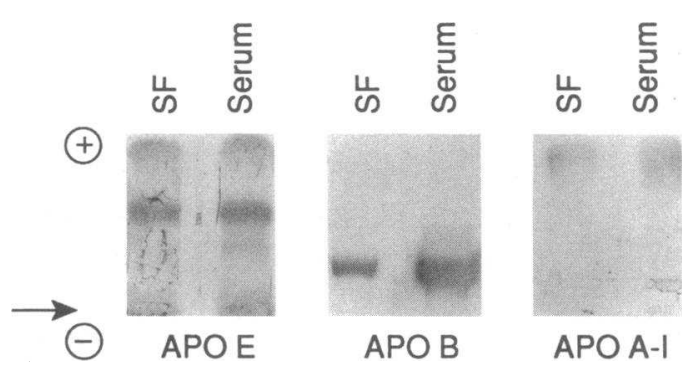

Figure 5. Charge distribution of apo E-bearing particles in synovial fluids. Samples from a patient with osteoarthritis (Table II, patient No. 3) were electrophoresed on agarose strips under nondenaturing conditions, developed in barbital buffer, and probed for apolipoproteins after transfer by capillary filtration to nitrocellulose as described in Methods. Arrow indicates origin. Representative of results from three separate osteoarthritis patients. classes of apo E-bearing lipoproteins in noninflammatory synovial fluid were identical to the classes of particles present in simultaneously drawn matching serum (Figs. 2 and 5). Therefore, synovial fluid apo $\mathrm{E}$ was associated with more than a single class of lipoproteins, similar to the profile of circulating apo E-bearing lipoproteins.

\section{Discussion}

Apo $\mathrm{E}$ is increasingly recognized to have functions which could modulate inflammation and tissue repair (15). Because apo $E$ is a constituent of some plasma lipoproteins it would be expected to readily enter inflammatory loci such as synovial fluids attendant to local increases in vascular permeability (36). In this study, we have demonstrated that apo $E$ is enriched relative to apo B-100 and apo A-I in inflammatory and in noninflammatory synovial fluids (Tables I and II). This observation, and the presence in synovial fluid of sialylated apo E compatible with newly secreted apo E of extrahepatic origin (Fig. 4), as well as the demonstration of the secretion of apo $E$ in tissue culture by synoviocytes, all suggest local articular synthesis of apo E.

These findings are similar to the relative elevation of the peripheral fluid/plasma ratio of apo E previously described in human lymphatic fluid (36), and in human cerebrospinal fluid, where apo $\mathrm{E}$ is present at $\sim 5 \%$, and apo $\mathrm{B}$ and apo A-I only at $<1 \%$, of their respective plasma concentrations $(40,41)$. Constitutive local apo E synthesis, e.g., by macrophage lineage cells and by cells of the nervous system (41), is believed to cause enrichment of apo $E$ in lymph and cerebrospinal fluid, and has been similarly supported by evidence that cerebrospinal fluid apo $\mathrm{E}$ is more heavily sialylated than plasma apo $\mathrm{E}(41)$. In the case of synovial fluids, it is conceivable that local enrichment of apo $E$ is a result not only of local synthesis but also of preferential immobilization of apo $\mathrm{E}$ via high-affinity binding to glycosaminoglycans $(42,43)$, which are present at high levels within synovial fluid and articular cartilage (25).

Apo $E$ is clearly associated with more than a single class of particles in noninflammatory synovial fluid (Figs. 2 and 5), including lipoproteins of alpha electrophoretic mobility (HDL) (Fig. 5). This supports work done by Small and co-workers before the discovery of apo E (44), demonstrating that human synovial fluids contain substantial amounts of HDL 1 , the major apo E-bearing HDL subclass $(15,45)$. Newly synthesized apo $\mathrm{E}$ has recently been shown to preferentially associate with filtered HDL particles in canine interstitial fluids $(46,47)$. Thus, it is likely that HDL-bearing apo E can also be assembled in synovial fluids.

The physiological significance of local anticular apo E synthesis likely includes the role of apo $\mathrm{E}$ in membrane resynthesis, as illustrated in repair of neural injury $(15,19)$. Potent suppression by apo $\mathrm{E}$ of lymphocyte activation by mitogens and antigens is also well recognized (20-23), and emphasizes that apo $\mathrm{E}$ can possess tissue-specific paracrine functions (48). Apo E secretion from monocyte/macrophages is increased by cholesterol loading (49), suggesting the possibility that synovial apo E production could be enhanced by the exposure of these cells to cellular debris, platelets $(50)$, and intraarticular, oxidized LDL (51). Importantly, macrophage apo E secretion is suppressed by endotoxin (52) and certain particulates (53), suggesting that modulation of apo $\mathrm{E}$ secretion is one mechanism for macrophages to relate their state of activation to neighboring lymphocytes $(14,22)$. Thus, the extent of local apo E pro- 
duction has the potential to modulate immune responses to antigens filtered into synovial tissues.

Leukocyte activation by urate crystals is important in the pathogenesis of gouty inflammation $(1,4)$. The results of this study suggest that the binding of apo $E$ to intraarticular monosodium urate crystals (Fig. 1) may have functional consequences via the potent suppression of the capacity of urate crystals to stimulate neutrophils (Fig. 3). Apo B-100 also inhibits urate crystal-induced neutrophil activation by binding to the crystal surface (13). Apo E, like apo B-100, possesses domains enriched in positively charged amino acids, and some of these regions mediate high-affinity binding to polyanionic glycosaminoglycans such as heparin $(42,43,54,55)$. Because urate crystals are also polyanionic (5), we are investigating the possibility that one or more of these regions could modulate the binding of apo $\mathrm{E}$ to urate crystals and mask areas on the crystal surface necessary to induce neutrophil activation. In addition, we are evaluating the potential for apo $\mathrm{E}$ to affect leukocyte activation by other inflammatory surfaces.

In summary, human synovial fluids contain apo $E$ that appears to be partly of local origin. The potential functions of apo $E$ in normal and inflamed joints, and in the regulation of the inflammatory potential of the urate crystals in gouty tophaceous deposits and synovial fluids merit further investigation.

\section{Acknowledgments}

The authors gratefully acknowledge the technical assistance of Linda Francis, Joe Juliano, and D. J. Bonnett. Dr. Steve Young and Dr. Richard Smith provided useful suggestions and valuable assistance with apolipoprotein measurements. Dr. Gary Firestein and Dr. Peter Fowler generously provided synovial fluids. Lois Diamond prepared the manuscript.

Supported by the Veterans Administration Research Service, and National Institutes of Health grants AM-36702 and HL-35297. Dr. Terkeltaub is the recipient of an Arthritis Investigator Award from the Arthritis Foundation.

\section{References}

1. Agudelo, C. A., and H. R. Schumacher. 1973. The synovitis of acute gouty arthritis. A light and electron microscopic study. Hum. Pathol. 4:265-279.

2. DiGiovine, F. S., S. E. Malawista, G. Nuki, and G. W. Duff. 1987. Interleukin 1 (IL-1) as a mediator of crystal arthritis: stimulation of $T$ cell and synovial fibroblast mitogenesis by urate crystal-induced IL-1. J. Immunol. 138:32133218.

3. Guerne, P. A., R. Terkeltaub, B. Zuraw, and M. Lotz. 1989. Inflammatory microcrystals stimulate interleukin- 6 production and secretion by human monocytes and synoviocytes. Arthritis Rheum. 32:1442-1452.

4. Terkeltaub, R., M. H. Ginsberg, and D. J. McCarty. 1989. Pathogenesis and treatment of crystal-induced inflammation. In Arthritis and Allied Conditions. 11 th ed. D. J. McCarty, editor. Lea and Febiger, Philadelphia. 1691-1710.

5. Levinson, D. J. 1989. Clinical gout and the pathogenesis of hyperuricemia. In Arthritis and Allied Conditions. 11 th ed. D. J. McCarty, editor. Lea and Febiger, Philadelphia. 1645-1676.

6. Hasselbacher, P., and H. R. Schumacher. 1978. Immunoglobulin in tophi and on the surface of monosodium urate crystals. Arthritis Rheum. 21:353-361.

7. Sokoloff, L. 1957. The pathology of gout. Metabolism. 6:230-243.

8. Kozin, F., M. H. Ginsberg, and J. L. Skosey. 1979. Polymorphonuclear leukocyte responses to monosodium urate crystals: modification by adsorbed serum proteins. J. Rheumatol. 6:519-526.

9. Terkeltaub, R., A. J. Tenner, F. Kozin, and M. H. Ginsberg. 1983. Plasma protein binding by monosodium urate crystals: analysis by two-dimensional gel electrophoresis. Arthritis Rheum. 26:775-783.

10. Terkeltaub, R., L. K. Curtiss, A. J. Tenner, and M. H. Ginsberg. 1984 Lipoproteins containing apoprotein B are a major regulator of neutrophil responses to monosodium urate crystals. J. Clin. Invest. 73:1719-1730.

11. Abramson, S., S. T. Hoffstein, and G. Weissmann. 1982. Superoxide anion generation by neutrophils exposed to monosodium urate: effect of protein adsorption and complement activation. Arthritis Rheum. 25:174-180.

12. Terkeltaub, R., R. D. Smeltzer, L. K. Curtiss, and M. H. Ginsberg. 1986. Low density lipoprotein inhibits the physical interaction of phlogistic crystals and inflammatory cells. Arthritis Rheum. 29:363-370.

13. Terkeltaub, R., J. Martin, L. K. Curtiss, and M. H. Ginsberg. 1986. Apolipoprotein B mediates the capacity of low density lipoprotein to suppress neutrophil stimulation by particulates. J. Biol. Chem. 261:15662-15667.

14. Lin, C.-T., Y. Xu, J.-Y. Wu, and L. Chan. 1986. Immunoreactive apolipoprotein $\mathrm{E}$ is a widely distributed cellular protein. J. Clin. Invest. 78:947-958.

15. Mahley, R. W. 1988. Apolipoprotein E: cholesterol transport protein with expanding role in cell biology. Science (Wash. DC) 240:622-630.

16. Basu, S. K., Y. K. Ho, M. S. Brown, D. W. Bilheimer, R. G. W. Anderson, and J. L. Goldstein. 1982. Biochemical and genetic studies of the apoprotein $E$ secreted by mouse macrophages and human monocytes. J. Biol. Chem. 257:9788-9795.

17. Wemette-Hammond, M. E., S. J. Laver, A. Corsini, D. Walker, J. M. Taylor, and S. C. Rall, Jr. 1989. Glycosylation of human apolipoprotein E: the carbohydrate attachment site is threonine 194. J. Biol. Chem. 264:9094-9101.

18. Beisiegel, U., W. Weber, G. Ihrke, J. Herz, and K. K. Stanley. 1989. The LDL-receptor-related, LRP, is an apolipoprotein E-binding protein. Nature (Lond.). 341:162-164.

19. Boyles, J. K., C. D. Zoellner, L. J. Anderson, L. M. Kosik, R. M. Pitas, K. H. Weisgraber, D. Y. Hui, R. W, Mahley, P. J. Gebicke-Haerter, M. J. Ignatius, and E. M. Shooter. 1989. A role for apolipoprotein A-I and low density lipoprotein receptors in cholesterol transport during regeneration and remyelination of the rat sciatic nerve. J. Clin. Invest. 83:1015-1931.

20. Curtiss, L. K., and T. S. Edgington. 1976. Regulatory serum lipoproteins: regulation of lymphocyte stimulation by a species of low density lipoprotein. $J$. Immunol. 116:1452-1458.

21. Hui, D. Y., J. A. K. Harmony, T. L. Innerarity, and R. W. Mahley. 1980. Immunoregulatory plasma lipoproteins. Effects of apoprotein $\mathrm{E}$ and apoprotein B. J. Biol. Chem. 255:11775-11781.

22. Pepe, M. G., and L. K. Curtiss. 1986. Apolipoprotein E is a biologically active constituent of the normal immunoregulatory lipoprotein, LDL-In. J. Immunol. 136:3716-3723.

23. Cardin, A. D., T. L. Bowlin, and J. L. Krstenansky. 1988. Inhibition of lymphocyte proliferation by synthetic peptides homologous to human plasma apolipoproteins B and E. Biochem. Biophys. Res. Commun. 154:741-745.

24. McCarty, D. J. 1988. Crystal identification in human synovial fluids: methods and interpretation. Rheum. Dis. Clin. North Am. 14:253-268.

25. Dahl, L. B., I. M. Bahl, A. Engstran-Laurent, and K. Granath. 1985. Concentration and molecular weight of sodium hyaluronate in synovial fluid from patients with rheumatoid arthritis and other arthropathies. Annu. Rheum. Dis. 44:817-822.

26. Curtiss, L. K., and T. S. Edgington. 1986. Immunologic heterogeneity of human plasma high density lipoproteins. J. Biol. Chem. 260:2982-2993.

27. Takagi, Y., C. A. Dyer, and L. K. Curtiss. 1988. Platelet-enhanced apolipoprotein $\mathrm{E}$ production by human macrophages: a possible role in atherosclerosis. J. Lipid Res. 29:859-867.

28. Hogle, D. M., R. S. Smith, and L. K. Curtiss. 1988. Quantitation of plasma apo A-I using two monoclonal antibodies in an enzyme-linked immunoabsorbent assay. J. Lipid Res. 29:1221-1229.

29. Young, S. G., R. S. Smith, D. M. Hogle, and L. K. Curtiss. 1986. Two new monoclonal antibody-based enzyme linked assays of apo-lipoprotein B. Clin. Chem. 32:1484-1490.

30. Markwell, M. A., S. M. Haas, L. L. Bieber, and N. E. Tolber. 1978. A modification of the Lowry procedure to simplify protein determination in membrane and lipoprotein samples. Anal. Biochem. 87:206-210.

31. Blance, P. J., E. L. Gong, T. M. Forte, and A. V. Nicholas. 1981. Characterization of human high-density lipoproteins by gradient gel electrophoresis. Bio chim. Biophys. Acta. 665:408-419.

32. Brandt, K. D. 1974. The effect of synovial hyaluronate on the ingestion of monosodium urate crystals by leukocytes. Clin. Chim. Acta. 55:307-315.

33. Klareskog, L., U. Forsum, U. Malmnas-Tjernlund, D. Kabelitz, and A. Wigren. 1981. Appearance of anti-HLA-DR reactive cells in normal and rheumatoid synovial tissue. Scand. J. Immunol. 14:183-192.

34. Schaeffer, E. J., and R. I. Levy. 1985. Pathogenesis and management of lipoprotein disorders. N. Engl. J. Med. 312:1300-1310.

35. Kushner, I., and J. A. Somerville. 1971. Permeability of human synovial membrane to plasma proteins: relationship to molecular size and inflammation. Arthritis Rheum. 14:560-570.

36. Sloop, C. H., L. Dory, and P. Roheim. 1987. Interstitial fluid lipoproteins. J. Lipid Res. 28:225-237.

37. McCarty, D. J. 1989. Synovial fluid. In Arthritis and Allied Conditions. 11 th ed. D. J. McCarty, editor. Lea and Febiger, Philadelphia. 61-90.

38. Blum, C. B., L. Aron, and R. Sciacca. 1980. Radimmunoassay studies of human apolipoprotein E. J. Clin. Invest. 66:1240-1250.

39. Gibson, J. C., A. Rubinstein, P. R. Bukbery, and W. V. Brown. 1983. 
Apolipoprotein E-enriched lipoprotein subclasses in normolipidemic subjects. $J$. Lipid Res. 24:886-898.

40. Roheim, P. S., M. Carey, T. Forte, and G. L. Vega. 1979. Apolipoproteins in human cerebrospinal fluid. Proc. Natl. Acad. Sci. USA. 76:4646-4649.

41. Pitas, R. E., J. K. Boyles, S. H. Lee, D. Hui, and K. H. Weisgraber. 1987. Lipoproteins and their receptors in the central nervous system. Characterization of the lipoproteins in cerebrospinal fluid and identification of apolipoprotein B, E (LDL) receptors in the brain. J. Biol. Chem. 262:14352-14360.

42. Wesigraber, K. H., S. C. Rall, Jr., R. W. Mahley, R. W. Milne, Y. L. Marcel, and J. T. Sparrow. 1986. Human apolipoprotein E. Determination of the heparin binding sites of apolipoprotein E3. J. Biol. Chem. 261:2068-2076.

43. Cardin, A. D., N. Hirose, D. T. Blankenship, R. L. Jackson, and J. A. K Harmony. 1986. Binding of a high reactive heparin to human apolipoprotein $\mathrm{E}$ identification of two heparin-binding domains. Biochem. Biophys. Res. Com mun. 134:783-789.

44. Small, D. M., A. S. Cohen, and K. Schmid. 1964. Lipoproteins of synovia fluid as studied by analytical ultracentrifugation. J. Clin. Invest. 43:2070-2079. 45. Gordon, V., T. Innerarity, and R. W. Mahley. 1983. Formation of cholesterol-and apoprotein E-enriched high density lipoproteins in vitro. J. Biol. Chem 258:6202-6212.

46. Sloop, C. H., L. Dory, R. Hamilton, B. R. Krause, and P. S. Roheim. 1983. Characterization of dog peripheral lymph lipoproteins: the presence of a discshaped nascent high density lipoprotein. J. Lipid Res. 24:1429-1440.

47. Dory, L., L. M. Boquet, C. R. Tate, and C. H. Sloop. 1986. Peripheral synthesis and isoform distribution of dog apoprotein $\mathrm{E}$ : an in vivo approach. $J$. Biol. Chem. 261:811-816.
48. Dyer, C. A., and L. K. Curtiss. 1988. Apoprotein E-rich high density lipoproteins inhibit ovarian androgen synthesis. J. Biol. Chem. 263:1096510973.

49. Mazzone, T., H. Gump, P. Diller, and G. S. Getz. 1987. Macrophage free cholesterol content regulates apolipoprotein E synthesis. J. Biol. Chem. 262:11657-11662.

50. Curtiss, L. K., A. S. Black, Y. Takagi, and E. F. Plow, 1987. New mechanism for foam cell generation in atherosclerotic lesions. J. Clin. Invest. 80:367373.

51. Cuthbert, J. A., P. L. Jeffrey, and P. E. Lipsky, 1989. Iron- or copper-dependent lipid peroxidation of lipoproteins at inflammatory sites: potential role in the mediation of tissue damage. In Copper and Zinc in Inflammation. Inflammation and Drug Therapy Series, Vol. IV. R. Milanino, K. D. Rainsford, and G. P. Velo, editor. Kluwer Academic Publishers, Boston. 33-48.

52. Werb, Z., and J. R. Chin. 1983. Endotoxin suppresses expression of apoprotein $\mathrm{E}$ by mouse macrophages in vivo and in culture. $\mathrm{A}$ biochemical and genetic study. J. Biol. Chem. 258:10642-10648.

53. Takemura, R., and Z. Werb. 1984. Modulation of apoprotein E secretion in response to receptor-mediated endocytosis in resident and inflammatory macrophages. J. Exp. Med. 159:167-178.

54. Weisgraber, K. H., and S. C. Rall, Jr. 1987. Human apolipoprotein B-100 heparin-binding sites. J. Biol. Chem. 262:11097-11103.

55. Hirose, N., D. T. Blankenship, M. A. Krivanek, R. L. Jackson, and A. D. Cardin. 1987. Isolation and characterization of four heparin-binding cyanogen bromide peptides of human plasma apolipoprotein B. Biochemistry 26:55055512 